\title{
Transparency and Accountability: The Province of Monza and Brianza Experience*
}

\author{
Erminia Vittoria Zoppè ${ }^{* *}$, Marta Caratti ${ }^{* * *}$
}

\begin{abstract}
The Open Government strategy is directed to supply a new institutional communication paradigm based on access and reuse of data and information and on the participation of the stakeholders. The focus is mostly centered on the opportunities that transparency, as a strategic asset, offers in order to repositioning the image of the Province, the subject of a deep institutional reorganization. In particular, the synergy produced by both the legal requirements to transparency and the recent innovations introduced by Legislative Decree 97/2016 foster new perspectives in order to consider this intermediate institution an open-access subject able to provide stakeholders with information, data and clear, timely and constantly updated documents.
\end{abstract}

Keywords: Transparency; Accountability; OpenData; Open Government; Stakeholder Engagement; Global Markets

\section{Monza and Brianza: the Portrait of a Young Province}

The Province of Monza and Brianza is a young institution: established in 2009 after the separation from Milan, it had immediately to deal with the complexities of a still ongoing reform process, one characterized by several criticalities.

Constituted of 55 municipalities, most with over 5.000 inhabitants, the Province of Monza and Brianza covers only 405.5 sq. Km of surface. One of the most urbanized area in Italy, it is worldwide well-known for its marked commercial and industrial vocation. With over 90,000 companies recorded in the Register of the Chamber of Commerce ${ }^{i}$, the local economic fabric has not surrendered to the difficulties and transformations of the last years, and it has always sought new opportunities, "believing in the economic enterprise as a form of social expression, as the best device to improve the life of a community and as a form of personal

\footnotetext{
* Invited Article

** Director of Area Resources and Services, Province of Monza and Brianza (e.zoppe@provincia.mb.it)

*** Former Head of the Institutional Communication Services, Web Communication and the Office of the Presidency (mcaratti@comune.monza.it)
}

Edited by: ISTEI - University of Milan-Bicocca

ISSN: 1593-0319

Zoppè, E.V. \& Caratti, M. (2017). Transparency and Accountability: the Experience of the Province of Monza and Brianza, Symphonya. Emerging Issues in Management (symphonya.unimib.it), 2, 5764. 
fulfillment. A widespread, almost contagious motivating force that contributed to guarantee a high birth rate - about 10 companies established every day - with a growth index of $0.8 \% "$. ii

Moreover, the ability to go beyond the limits - a characteristic and common feature of the economic fabric of the Province, culturally and historically inclined to trading with foreigners - allows to expand the economic horizon every day. In 2015 it brought the Province of Monza and Brianza to reach the $13^{\text {th }}$ place nationwide among the Italian provinces for export value (Table 1).

Table 1: Brianza 2005 - Facts and Figures

\begin{tabular}{|l|c|}
\hline Number of Economic Enterprises & 90378 \\
\hline Enterprises per sq.km. & 156 \\
\hline Wood and Furniture & 2161 \\
\hline High-Tech & 4749 \\
\hline Export 2015 & 9.092 .566 .925 Euro \\
\hline Export Wood and Furniture & 845.053 .298 Euro \\
\hline
\end{tabular}

Source: Study of Chamber of Commerce of Monza and Brianza based on Business Register data, ISTAT coeweb.

This outstanding economic result has been supported by the Province: the institution has been working in accordance with the world of business and the institutional stakeholders, to support the development processes and the fast transformation involving the territory in recent years.

\section{The Challenge of Change and the Italian Provinces}

The Province of Monza and Brianza, like other Italian Provinces, has been recently at the center of a deep institutional reorganization: the still in progress process has been activated through the Law 56/14 "Provisions on metropolitan cities, provinces, and the unions and mergers of municipalities". According to the Law the Provinces have been transformed in "wide area entities" iii which are ruled by bodies elected by the Mayors and Councillors of the territorial Municipalities.

The Law (Articles 1, 85 and 86) entrusts to the Provinces several fundamental and exclusive competences regarding:

- territory and environment: coordination of the developing planning of the provincial territory, as well as protection and enhancement of the environment, according to the power of exclusive competence;

- transport and road management: planning of the provincial transport services, authorization and control of private transport according to the regional planning, as well as the construction and management of provincial roads and the regulation of traffic on the roads of competence;

- school: school buildings management and planning of the provincial school network, in compliance with regional planning; 
- equal opportunities: monitoring of discriminatory phenomena in the workplace and promotion of equal opportunities in the provincial territory;

- coordination: collection and processing of data, technical-administrative assistance to the local authorities.

Additional territorial network functions - not fundamental (Articles 1, 88) - regard the duties of preparing tender documents, procurement stations, monitoring of service contracts and organizing competitions and selective procedures -

In addition, some administrative functions of exclusive competence of the state have been assigned and/or transferred by prior agreement among the State and Regions.

The implementation of the amendments to the body of state legislation has been heavily influenced by the budgetary margin of maneuver introduced between 2013 and 2016, which - by imposing a reduction of resources of 5.2 billion euros (source UPI, February 2017) - caused a widespread financial emergency among the territorial institutions. The fact that the Provinces were considered "institutions waiting for a general constitutional reform" or objects of a complete abolition has seriously compromised the delivery of the essential services traditionally supplied by these institutions.

The outcome of the constitutional referendum held on $4^{\text {th }}$ December 2016 rejected the proposal to abolish the Provinces, thus maintaining the institution as an integral part of the national institutional structure. According to the Constitution:

"The Republic is composed of the Municipalities, the Provinces, the Metropolitan Cities, the Regions and the State" (Article 114);

"Provinces carry out administrative functions on their own" (Art.117 and 118);

"Provinces shall have revenue and expenditory autonomy; revenues raised from the above-mentioned sources shall enable provinces to fully finance the public functions attributed to them" (Art.119).

\section{The Province and the Network of Brianza Municipalities}

The so called Delrio Law imposed an irreversible process of transformation of the Provinces which - in particular as a consequence of the outcome of the referendum - should reconsider their strategic role and institutional mission. Indeed, this intermediate institution has been asked to act as an "hub" on behalf of the municipalities and the territory. Therefore the Provinces are asked to implement their role of direction, coordination and connection with and among the Municipalities. In the last years the efforts of the Province have been producing worthwhile results in order to respond these tasks.

In this framework, since 2015 the Province of Monza and Brianza has been testing a set of "network services" dedicated to the 55 Municipalities of the territory. (Table 2).

Among the services, it is worth mentioning the Single Customer Service Centre (CUC) to centralize tenders and plan the purchase of goods and services.

To date 38 municipalities and 2 subsidiary companies are associated with the CUC of the Province of Monza and Brianza; in 2016 the CUC launched more than 80 tendering procedures for a total amount of 36,227,600 euros. 
Table 2: Territorial Network Services Projects

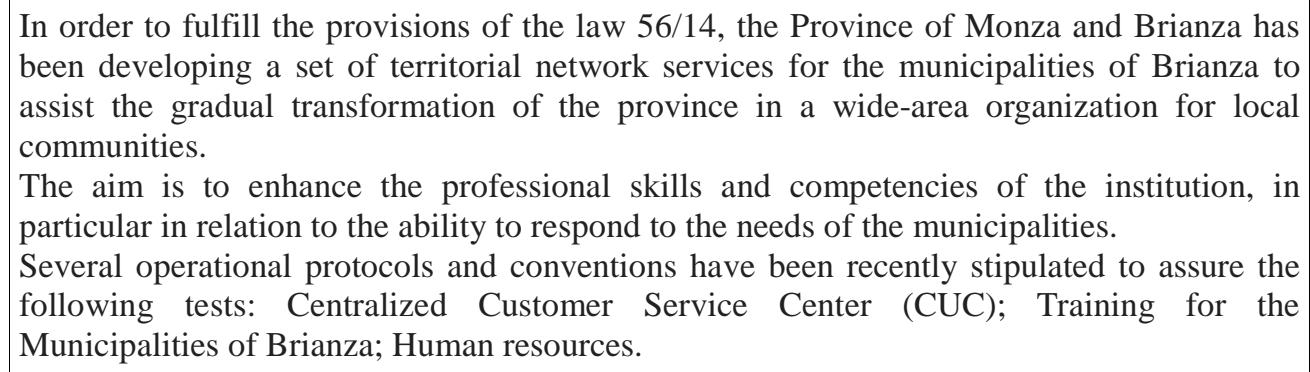

Source: Progetti di rete territoriale, Province of Monza and Brianza (2017).

In this historical moment the public image of the Provinces has been posed under scrutiny by public opinion. As a consequence, the institutional communication activity needs to improve its ability to offer useful and high-quality services, despite the difficulties caused by the continuous budget cuts.

Therefore in the interest of the institution, it has been necessary to enhance the role of specific assets such as innovation, participation and transparency and promote the consolidation of the 'House of Municipalities' territorial network.

It clearly appears that the choice to privilege the public service communication through the increasingly popular web 2.0 channels - and to enhance the offer of marketing services to the Municipalities network may be decisive to reposition the brand of the institution and strengthen the community of Municipalities.

Thus, the idea to develop an information asset of the Wide Area, using the Opendata as the starting step to set up the first platform of know-how and disseminate the digital culture for the benefit of the local authorities. By enhancing relational capital the institution is committed to increase the networking capacity of the stakeholders.

In this context, administrative transparency became an essential factor in order to develop and innovate the approach to the indications introduced by Legislative Decree 33/2013. Indeed, while initially the decree has been experienced simply as the fulfillment of administrative obligations - often characterized by the burden of collecting and organizing online data - now it is perceived as a valuable opportunity for the strategic relaunch of the Province.

Transparency has provided several opportunities to review standard procedures in the perspective to improve simplification, in particular responding to the need to introduce the computerized document management system. The decision to immediately fulfill the provisions introduced by the above mentioned Legislative Decree (in particular the requirement to publish data, documents and information) contributed to simplify several data collection procedures, with particular positive effects on:

- Administrative Measures (Article 23 of Legislative Decree 33/13);

- Grants, subsidies and the granting of economic benefits to individuals and public and private bodies (Article 26 of Legislative Decree 33/13);

- List of beneficiaries (Article 27 of Legislative Decree 33/13);

- Public contracts for the supply of products and services (Article 37 of Legislative Decree 33/13). 
In addition, the choice to enter the platform "Lombardy Digital Agenda" - the project launched by the Lombardy Region - allowed to introduce the principle of the reuse of data, making the Province of Monza and Brianza one of the four institutions accredited by the Region with its own site.

\section{Transparency and Accountability}

With these premises, the strategic role of administrative transparency, even in terms of OpenData access, constitutes a strategic tool to drive the process of institutional transformation of the Province in order to provide clear, timely, transparent and constantly updated information to citizens, the business world, institutional stakeholders and the mass media. This will affect on the reference scenario and the new institutional and / or organizational arrangements, but especially on the problems related to the delivery of services. In fact, the development of OpenGovernment tools, primarily in terms of access and simplification, is a key factor in encouraging innovation, participation and re-use policies. These elements will legitimize the institution's accountability in the new role of the Province as service provider for the territory. Alongside these developments, the institution will commit to ensuring the full implementation of the new regulations introduced in the Legislative Decree 97/2016 regarding advertising, transparency and distribution of information.

\section{The Online 'Transparency Day'}

Since three years, in accordance with the Legislative Decree 33/2013, the Province has activated the on-line Transparency Day (Table 3). By using innovation as a driving force, the institution sought to pursue and improve the administrative transparency as a lever of/for change and a chance to introduce a new work style.

$\square$ Each administration submits its Plan and Performance Report [...] to consumer associations, users, research centers and any other qualified observer, during established Transparency Day [...]. (Art.10, c.6 Leg. Decree 33/13).

Therefore, it has been decided to introduce a non-traditional formula for the Transparency Day. It occurs only on the web and the social networks, and it is devoted to deepen and explain the contents of the 'Transparent Administration' site. During the Transparency Day, the Institutional Site of the Province (www.provincia.mb.it) works as the gateway for all stakeholders, a landing page on which the visitor, through a clearly visible menu, may access the most relevant contents, including video interviews uploaded on the Youtube channel, data and information on the issue of transparency. Since 2016 visitors may access the new specific section 'Wide Area' where a collection of datasets - including tabular and cartographic data - covering the area of Brianza included in the provinces of Como and Lecco are available. On the occasion of the Transparency Day, every year new contents and datasets are released in accordance with the standards set by the 
Lombard Digital Agenda. All these data are collected and processed in the MB Open Data section (www.provincia.mb.it/MBOpenData).

Thus, the yearly Transparency Day has been transformed in a specific occasion for the Province to metaphorically open the drawers of its offices and share the gathered know-how, in the perspective of openness and participation.

\section{The Experience of the MBOpendata Web Portal}

With the implementation of the MBOpendata project, approved by Presidential Decree no. 25 of $27 / 11 / 2014$, the Province has begun experimenting with a knowledge sharing tool. This instrument implements the OpenGov's policies in the perspective of new, open and participative culture of the administration and politics with the aim to produce beneficial effects on the complex governance of a local democracy. The adjective 'open' and the 'concept of openess' become the key factors in structuring and implementing public policies because both facilitate the production of more democratic collective decisions. These decisions are the result of the increased participation, one stimulated by greater transparency, "the best disinfectant in democracy", to quote US Supreme Court Justice Louis Brandeis ${ }^{\mathrm{iv}}$. To conclude: at the end of this first experimental step - implemented in collaboration with the Lombardy Region, according to the standards set by AGID (Agency for Digital Italy) - one must underline that the Provincia of Monza and Brianza issued 79 datasets: 50 tabular data, 18 maps, and 11 graphic representations of data. They concern researches and analysis, collection and elaboration of data that the Province - in its role of 'House of the Municipalities' - primarily offers to the 55 municipalities, to citizens, businesses and institutional stakeholders: the set of knowledge - containing useful data and information, ready for reuse - is offered in open format, access-free and downloadable to favour the development of apps, programs, and services.

- Among the most viewed data sets (also shared on the Lombardy Region portal) (www.dati.lombardia.it/provincia-mb):

- the list of Municipalities of the Province with over 7,000 views;

- the list of high schools in the territory of Brianza with approximately 1,000 views and over 303 downloads;

- the list of travel agencies with 800 views;

- the map of SIF wells (Sistema Informativo Falda/Aquifer Information System) of the Province, with about 400 views.

We are aware that this is certainly a first experimentation whose aim is to further improve the development of OpenGov as a chance to contribute to the growth of the whole country, in particular concerning the unsatisfactory international positioning on the issue, since the gap to recover is undeniable. In this regard, the up-to-date data released by the United Nations E-Government Survey in 2016, indicates that Italy does not appear in the top 10 places of the E-Government Development Index, while it is placed in the tenth place in the E- participation index.

Table 4: E-Government Development Index and E-Participation Index 


\begin{tabular}{|l|c|l|c|}
\hline $\begin{array}{c}\text { E-Government } \\
\text { development index }\end{array}$ & $\begin{array}{c}\text { E-Partecipation } \\
\text { index }\end{array}$ & \multicolumn{2}{|c|}{ E-Participation index } \\
\hline Country & Index & Country & Index \\
\hline United Kingdom & 0,9193 & United Kingdom & 1,0000 \\
\hline Australia & 0,9143 & Japan & 0,9831 \\
\hline Republic of Korea & 0,8915 & Australia & 0,9831 \\
\hline Singapore & 0,8828 & Republic of Korea & 0,9661 \\
\hline Finland & 0,8817 & Netherlands & 0,9492 \\
\hline Sweden & 0,8704 & New Zealand & 0,9492 \\
\hline Netherlands & 0,8659 & Spain & 0,9322 \\
\hline New Zealand & 0,8653 & Singapore & 0,9153 \\
\hline Demmark & 0,8510 & Canada & 0,9153 \\
\hline France & 0,8456 & Italy & 0,9153 \\
\hline \multicolumn{2}{r|}{} & Finland & 0,9153 \\
\cline { 3 - 4 }
\end{tabular}

Source: United Nations E-governement Survey (2016).

\section{Bibliography}

ANCI (2012). Guidelines on transparency and integrity for Local Authorities, Rome.

Bisio L. (2006), Public Governance and Financial Communication, Symphonya. Emerging Issues in Management (symphonya.unimib.it), 1, 110-128.

http://dx.doi.org/10.4468/2006.1.08bisio

Brondoni Silvio M., (2015) Global Networks, Outside-In Capabilities and Smart Innovation, Symphonya. Emerging Issues in Management (symphonya.unimib.it), 1, 6 - 21. http://dx.doi.org/10.4468/2015.1.02brondoni

Brondoni Silvio M. (2014) Global Capitalism and Sustainable Growth. From Global Products to Network Globalisation, Symphonya. Emerging Issues in Management (symphonya.unimib.it), 1, $10-31$.

http://dx.doi.org/10.4468/2014.1.02brondoni

Brondoni, S.M. (2006). Managerial Corporate Governance Communication, Symphonya. Emerging Issues in Management (symphonya.unimib.it), 1, 8-23.

http://dx.doi.org/10.4468/2006.1.02brondoni

Di Betta P., Amenta C. (2004). Incentives in Corporate Governance: the Role of Self-Regulation, Symphonya. Emerging Issues in Management (symphonya.unimib.it), 1, 43-57 http://dx.doi.org/10.4468/2004.1.05dibetta.amenta

Gnecchi F. (2006). Corporate Governance Communications, Symphonya. Emerging Issues in Management (symphonya.unimib.it), 1, 47-61 http://dx.doi.org/10.4468/2006.1.04gnecchi

Salvioni D. M., Bosetti L. (2014), Sustainable Development and Corporate Communication in Global Markets, Symphonya. Emerging Issues in Management (symphonya.unimib.it), 1, 1-19. http://dx.doi.org/10.4468/2014.1.03salvioni.bosetti

Salvioni D.M. \& Astori R. (2013). Sustainable Development and Global Responsibility in Corporate Governance, Symphonya. Emerging Issues in Management (symphonya.unimib.it), 1, 28-52. http://dx.doi.org/10.4468/2013.1.03salvioni.astori

Salvioni D. M., Bosetti L. (2006), Corporate Governance Report and Stakeholder View, Symphonya. Emerging Issues in Management, (symphonya.unimib.it), 1, 24-46.

http://dx.doi.org/10.4468/2006.1.03salvioni.bosetti

Sarcone V., Tartaglione M. (2015). Prevenzione della corruzione e trasparenza nelle amministrazioni pubbliche e negli altri soggetti pubblici e privati individuati dalla disciplina vigente, Sapidata, Gualdicciolo - Repubblica di San Marino (RSM). 
UPI (2011). UPI guidelines on performance, transparency and integrity in the Italian provinces, Rome.

Vurro C., Russo A., Costanzo L.A. (2014). Sustainability along the Value Chain: Collaborative Approaches and their Impact on Firm Performance, Symphonya. Emerging Issues in Management (symphonya.unimib.it), 2, $30-44$

http://dx.doi.org/10.4468/2014.2.04vurro.russo.costanzo

Zucchella, A. (2007). Network Social Responsibility, Symphonya. Emerging Issues in Management (symphonya.unimib.it), 2, 64-71

http://dx.doi.org/10.4468/2007.2.07zucchella

\section{Notes}

i Report 2016 Brianza Economy, Chamber of Commerce of Monza and Brianza

ii Report 2016 Brianza Economy, Chamber of Commerce of Monza and Brianza

iii The term "wide area" defines the level of planning and management of the territory, the resources and the relationships among these intermediate institutions, the Municipalities and the Region. 